\title{
PENGEMBANGAN PERANGKAT PEMBELAJARAN BERBASIS MASALAH UNTUK MENINGKATKAN KEMAMPUAN PEMECAHAN MASALAH SISWA SMA NEGERI 17 MEDAN
}

\author{
Randi Tampubolon ${ }^{1}$, Bornok Sinaga ${ }^{2}$, Mulyono $^{2}$
}

\begin{abstract}
ABSTRAK
Penelitian ini bertujuan untuk mengetahui: 1) tingkat kevalidan perangkat pembelajaran berbasis masalah dalam meningkatkan kemampuan pemecahan masalah, 2) tingkat keefektifan perangkat pembelajaran berbasis masalah dalam meningkatkan kemampuan pemecahan masalah , 3) tingkat kepraktisan perangkat pembelajaran berbasis masalah dalam meningkatkan kemampuan pemecahan masalah, 4) peningkatan kemampuan pemecahan masalah matematis siswa dalam penerapan perangkat pembelajaran berbasis masalah. Penelitian pengembangan ini menggunakan model pengembangan Dick and Carey dengan subjek kelas X SMA Negeri 17 Medan. Perangkat pembelajaran yang dihasilkan dari penelitian ini adalah RPP, LKPD, BPG, dan BS. Instrumen yang digunakan dalam penelitian ini yaitu lembar validasi, lembar observasi keterlaksanaan, dan test. Hasil dari penelitian ini menunjukkan bahwa : 1) Perangkat pembelajaran yang dikembangkan memenuhi kriteria valid baik dalam validitas isi dengan rata-rata 4,38 dan validitas konstruk dengan uji reabilitas $\mathrm{r}_{11}$ sebesar 0,$934 ; 2$ ) Perangkat pembelajaran yang dikembangkan memenuhi kriteria praktis dilihat dari respon guru siswa dan siswa menytakan praktis, keterlaksanaan perangkat $81,47 \%$ pada ujicoba I dan 89,13\% pada ujicoba II ; 3) Perangkat pembelajaran yang dikembangkan memenuhi kriteria efektif dilihat dari ketuntasan klasikal 38,89\% pada ujicoba I dan $91,67 \%$ pada ujicoba II, respon siswa 89,81\% pada ujicoba I dan 93,33\% pada ujicoba II ; 4) Terdapat peningkatan N-Gain kemampuan pemecahan masalah siswa menggunakan perangkat berbasis masalah yang dikembangkan pada ujicoba I sebesar 0,32 dalam kategori rendah meningkat pada ujicoba II sebesar 0,53 dalam kategori sedang.
\end{abstract}

Kata Kunci: Pengembangan Perangkat Pembelajaran, Pembelajaran Berbasis Masalah, Kemampuan Pemecahan Masalah, Model Dick and Carey

\section{PENDAHULUAN}

Belajar adalah suatu kegiatan yang dilakukan oleh seseorang untuk memperoleh kecakapan, keterampilan, dan sikap yang di dapatkan melalui pendidikan (Sinaga, 2008:11). Pendidikan merupakan upaya dalam mengembangkan dan meningkatkan potensi diri, sehingga dapat menyelesaikan berbagai permasalahan hidupnya. Tanpa disadari semua aktivitas manusia berhubungan erat dengan pendidikan. Bangsa yang maju adalah bangsa yang memiliki sumber daya manusia yang berkualitas, baik dari segi spritualitas, kecerdasan, juga keterampilan. Salah satu hal yang dapat dilakukan untuk dapat mencapai tujuan tersebut yaitu pembaharuan secara terus menerus dalam bidang pendidikan, khususnya pada mata pelajaran matematika. Matematika merupakan ilmu dasar yang digunakan untuk mengembangkan cabang ilmu lain (Safithri, et al, 2021:336).

Matematika memainkan peranan yang sangat penting dalam kehidupan. Ini dapat dilihat pada bantuan matematika dalam berbagai sektor kehidupan manusia, seperti pada komputasi, transportasi, komunikasi, ekonomi dan pengembangan ilmu pengetahuan dan teknologi. Matematika merupakan ilmu universal yang berguna bagi kehidupan manusia

\footnotetext{
${ }^{1}$ Corresponding Author: Randi Tampubolon

Guru SMAN 17 Medan, Medan, 20136, Indonesia

E-mail: matematikarandi@gmail.com

${ }^{2}$ Co-Author: Bornok Sinaga \& Mulyono

Program Studi Pendidikan Matematika Universitas Negeri Medan, Medan, 20221, Indonesia
}

dan juga mendasari perkembangan teknologi modern yang mempunyai peran penting dalam berbagai disiplin dan memajukan daya pikir manusia. Hasratuddin (2018:34) mendefinisikan matematika adalah suatu sarana atau cara untuk menemukan jawaban terhadap masalah yang dihadapi manusia; suatu cara menggunakan informasi, menggunakan pengetahuan tentang bentuk dan ukuran, menggunakan pengetahuan tentang menghitung, dan yang paling penting adalah memikirkan dalam diri manusia itu sendiri untuk melihat dan menggunakan hubungan-hubungan.

Berdasarkan hasil TIMSS (Trend in International Mathematics and Science Study) tahun 2015 menunjukkan siswa Indonesia berada di peringkat 44 dari 49 negara, dengan skor 397 dari skor 500 (Syamsul \& Novaliyosi, 2019: 563) . Hasil Program for International Student Assesment (PISA) tahun 2018 menunjukkan bahwa peserta didik Indonesia mendapat peringkat 72 dari 77 negara di dunia. Berdasarkan masih rendahnya kemampuan pemecahan masalah matematis peserta didik, perlu dikembangkan suatu perangkat pembelajaran yang dapat membantu peserta didik dalam meningkatkan kemampuan pemecahan masalahnya (Silalahi, et al, $2021: 114$ )

Kemampuan pemecahan masalah merupakan kemampuan siswa dalam menyelesaikan masalah matematika dengan mengamati proses dalam menemukan jawaban berdasarkan langkah-langkah pemecahan masalah, yakni memahami masalah, merencanakan pemecahan masalah, memecahkan masalah, dan mengecek ulang (Havill , 2020). 
Meskipun matematika merupakan mata pelajaran yang sangat penting dalam dunia pendidikan dan sangat banyak kaitannya dalam kehidupan sehari-hari, namun matematika masih saja dianggap sebagai momok yang menakutkan bagi siswa. Siswa cenderung takut dan merasa kesulitan dalam belajar matematika, umumnya pada masalah matematika yang dibuat sedemikan kompleks, sehingga siswa kesulitan untuk memecahkan masalah matematika, yang berakibat rendahnya kemampuan pemecahan masalah matematis siswa, adapun rendahnya kemampuan pemecahan masalah matematika siswa disebabkan oleh siswa mengalami kesulitan dalam memahami masalah matematika yang mempengaruhi proses pemecahan masalah (Bayuningsih et al., 2017:51)

Sejalan dengan hasil observasi awal di SMA Negeri 17 Medan, fakta menunjukkan bahwa kemampuan pemecahan masalah siswa mash rendah. Rendahnya kemampuan pemecahan masalah terlihat dari hasil tes diagnosis berupa soal cerita yang peneliti berikan kepada 36 siswa kelas X pada materi Trigonometri, yaitu : dari 36 siswa yang mengikuti tes diagnosis, hanya 12 siswa $(33,33 \%)$ yang lulus. Masalah yang terjadi sehingga kemampuan pemecahan masalah rendah yaitu guru kesulitan dalam menyusun perangkat pembelajaran matematika. Berdasarkan hasil wawancara terhadap guru bidang studi matematika di SMA Negeri 17 Medan, selama ini kemampuan pemecahan masalah siswa tidak menjadi fokus dalam kegiatan pembelajaran. Disisi lain, peneliti menemukan bahwa tidak ada guru yang memiliki perangkat pembelajaran yang berfokus untuk melatih kemampuan pemecahan masalah siswa.

Dalam upaya memperbaiki proses pengajaran dan pembelajaran matematika di kelas, maka dibutuhkan usaha untuk memperbaiki pemahaman guru dan siswa serta bahan yang digunakan untuk pembelajaran dan interaksi antara siswa dan guru. Pada pelaksanaan pembelajaran, perangkat pembelajaran sangat berperan penting dalam proses pembelajaran yang dimana tertuang dalam Permendikbud Nomor 65 Tahun 2013 tentang Standar Proses Pendidikan Dasar dan Menengah disebutkan bahwa penyusunan perangkat pembelajaran merupakan bagian dari perencanaan pembelajaran. Perangkat pembelajaran tersebut berupa Rencana Pelaksanaan Pembelajaran (RPP), Buku Siswa (BS), Lembar Kerja Peserta Didik (LKPD), instrumen evaluasi atau tes hasil belajar serta media pembelajaran. Sebagaimana diperkuat oleh pernyataan Sanjaya (Mustafa, 2020:163) yang menyatakan bahwa "guru mampu memprediksikan secara benar keberhasilan yang akan dicapai, melalui proses perencanaan yang matang dan akurat, disamping itu proses pembelajaran akan berkembang secara terarah dan terorganisir, serta guru dapat menggunakan waktu seefektif mungkin untuk memperoleh keberhasilan proses pembelajaran".

Agar tujuan pembelajaran mencapai sasaran yang diharapkan, maka perlu dilakukan pemilihan model pembelajaran tepat, serta perlu dilakukan pengembangan perangkat pembelajaran yang sesuai pula dengan model pembelajaran yang digunakan.
Model pembelajaran yang digunakan harus mampu membuat siswa aktif dalam kegiatan pembelajaran, membuat pembelajaran bermakna, serta mampu melatih siswa untuk terbiasa berpemecahan masalah dalam memecahkan masalah.

Pemilihan pembelajaran berbasis masalah merupakan salah satu solusi yang tepat. Berdasarkan pendapat Arends (Mustafa, 2020:163), pembelajaran berbasis masalah adalah model pembelajaran yang mendekatkan siswa pada masalah otentik dan bermakna kepada siswa, sehingga siswa dapat mengkontruksikan pengetahuannya sendiri, mengembangkan keterampilan dan inkuiri, kemandirian, dan meningkatkan rasa percaya diri siswa. Yang diperkuat oleh hasil penelitian Safithti, et al (2021:335) yang menemukan bahwa pembelajaran berbasis masalah dapat meningkatkan kemampuan pemecahan masalah dan self efficacy siswa.

Selanjutnya pengembangan perangkat pembelajaran berbasis masalah juga dapat meningkatkan kemampuan pemecahan masalah sebagaimana hasil penelitian Silalahi, dkk (2021: 213) menemukan bahwa pengembangan perangkat pembelajaran berbasis Problem Based Learning (PBL) dapat meningkatkan kemampuan pemecahan masalah siswa.

Berdasarkan masalah yang telah didekripsikan, maka tujuan penelitian ini adalah : 1) memvalidasi perangkat pembelajaran berbasis masalah yang dikembangkan untuk meningkatkan kemampuan pemecahan masalah siswa, 2) mempraktiskan perangkat perangkat pembelajaran berbasis masalah yang dikembangkan untuk meningkatkan kemampuan pemecahan masalah untuk meningkatkan kemampuan pemecahan masalah siswa, 3) mengefektifkan perangkat perangkat pembelajaran berbasis masalah yang dikembangkan untuk meningkatkan kemampuan pemecahan masalah untuk meningkatkan kemampuan pemecahan masalah siswa, 4) meningkatkan kemampuan pemecahan masalah dengan menggunakan perangkat pembelajaran berbasis masalah yang dikembangkan.

\section{KAJIAN TEORITIS \\ Kemampuan Pemecahan Masalah}

Secara umum pengertian kemampuan menurut KBBI (Kamus Besar Bahasa Indonesia) adalah suatu kesanggupan, kecakapan seseorang dalam melakukan sesuatu . Seseorang dikatakan memiliki kemampuan atau mampu apabila ia bisa dan sanggup melakukan sesuatu yang memang harus dilakukannya. Kemampuan merupakan tenaga (daya kekuatan) untuk melakukan suatu perbuatan. Kemampuan bisa juga merupakan kesanggupan bawaan sejak lahir, atau merupakan hasil latihan maupun praktek. Dari pengertian disimpulkan bahwa kemampuan adalah kesangggupan dalam melakukan sesuatu. Selanjutnya kemampuan matematika adalah kesanggupan dalam memecahkan permasalah yang berhubungan dengan permasalahan matematika.

Masalah dalam pembelajaran matematika merupakan pertanyaan yang harus dijawab atau direspon. Namun tidak semua pertanyaan otomatis 
akan menjadi masalah. Suatu pertanyaan akan menjadi masalah hanya jika pertanyaan itu menunjukkan adanya suatu tantangan yang tidak dapat dipecahkan oleh suatu prosedur rutin yang sudah diketahui oleh siswa. Dalam Department of Education (Safithri \& Huda , 2021:336) menyebutkan bahwa : "Apabila kita menerapkan pengetahuan matematika, keterampilan atau pengalaman untuk memecahkan suatu dilema atau situasi yang baru atau yang membingungkan, maka kita sedang memecahkan masalah". Karenanya, dapat terjadi bahwa suatu masalah bagi seseorang siswa akan menjadi "pertanyaan" bagi siswa lainnya karena ia sudah mengetahui prosedur untuk menyelesaikannya atau proses pemecahan masalah.

Untuk menjadi seorang pemecah masalah yang baik, siswa membutuhkan banyak kesempatan untuk menciptakan dan memecahkan masalah dalam bidang matematika dan dalam konteks kehidupan nyata. Pernyataan itu diperkuat oleh pernyataan Sinaga (2007:10) menyatakan bahwa “ kemampuan pemecahan masalah adalah kemampuan atau kompetensi strategi yang ditunjukkan siswa dalam memahami, memilih pendekatan, dan strategi pemecahan dan menyelesaikan model untuk menyelesaikan masalah".

Dengan belajar memecahkan masalah matematika, siswa akan belajar bagaimana berpikir, terbiasa rajin dan memiliki rasa ingin tahu, serta memiliki keyakinan dalam situasi asing bahwa mereka akan hidup dengan baik di luar kelas matematika. Menurut Polya (Mustafa, 2020:164) dalam menyelesaikan masalah ada 4 langkah yang harus dilakukan, yaitu: pertama kita harus memahami masalahnya; kita harus melihat dengan jelas apa yang dibutuhkan. Kedua, kita harus melihat bagaimana berbagai item terhubung, bagaimana hal-hal yang tidak diketahui dikaitkan dengan data, untuk mendapatkan ide solusi, untuk membuat rencana. Ketiga, kami menjalankan rencana kami. Keempat, kami melihat kembali solusi yang telah selesai, kami meninjau dan mendiskusikannya.

Secara sederhana bahwa indikator pemecahan masalah ada 4 langkah, yaitu: i) memahami masalah, ii) menyusun rencana, iii) melaksanakan rencana, dan iv) menengok kembali pemecahan masalah. Dalam penelitian ini, keempat indikator kemampuan pemecahan masalah yang dikemukakan oleh Polya akan digunakan sebagai pedoman dalam mengukur kemampuan pemecahan masalah matematis siswa.

\section{Pembelajaran Berbasis Masalah}

Pembelajaran berbasis masalah yang sering dikenal dengan Problem Based Instruction (PBI) atau Problem Based Learning $(P B L)$ merupakan model pembelajaran yang menggunakan masalah sebagai titik tolak (starting point) pembelajaran. Masalah-masalah yang dapat dijadikan sebagai sarana belajar adalah masalah yang memenuhi konteks dunia nyata (real world), yang akrab dengan kehidupan sehari-hari para siswa. Menurut Arends dalam Nisak (Swanti et al, 2021:9) menyatakan bahwa model pembelajaran berbasis masalah adalah salah satu pendekatan dalam pembelajaran agar peserta didik dapat menemukan solusi permasalahan nyata sehingga mempengaruhi pengetahuannya sendiri, meningkatkan kemandirian, percaya diri, kemampuan inkuiri dan kemampuan berpikir stadium tinggi. Oleh karena itu, perlunya ada model pembelajaran atau pendekatan yang efektif terhadap proses berpikir ditingkat yang lebih sulit terkait permasalahan matematika sehingga dapat dikaitkan dengan lingkungan sekitar seperti model problem based learning.

Menurut Surya, et al (2018:15) "PBL is a learning model that is designed to boost the morale of students active and get involved in their learning and experience can also hone, test and develop his thinking ability on an ongoing basis". Yang menyatakan bahwa PBL merupakan model pembelajaran yang dirancang untuk mendorong semangat siswa aktif dan terlibat dalam kehidupannya pembelajaran dan pengalaman dapat mengasah, menguji dan mengembangkan kemampuan berpikirnya secara berkelanjutan.

Indikator yang menunjukkan kemampuan pemecahan masalah Menurut Polya dalam Nuralam (Waluyo \& Nuraini, 2021: 3) antara lain:

a. Mengidentifikasi unsur-unsur yang diketahui, yang ditanyakan, dan kecukupan unsur yang diperlukan,

b. Merumuskan masalah matematika atau menyusun model matematika,

c. Menerapkan strategi untuk menyelesaikan berbagai masalah (sejenis dan masalah baru) dalam atau di luar matematika,

d. Menjelaskan atau menginterpretasikan hasil sesuai permasalahan asal, dan

e. Menggunakan matematika secara bermakna.

Sejalan dengan pendapat dari Ibrahim \& Nur (Hutagalung, 2021:5) Aktivitas-aktivitas yang tercakup dalam kegiatan pemecahan masalah meliputi: (1) mengidentifikasi unsur yang diketahui, ditanyakan, serta kecukupan unsur yang diperlukan,(2) merumuskan masalah situasi sehari-hari dan metematik; menerapkan strategi untuk menyelesaikan berbagai masalah (sejenis dan masalah baru) dalam atau luar matematika,(3) menjelaskan/ menginterpretasikan hasil sesuai masalah asal,(4) menyusun model matematika (5) menyelesaikannya untuk masalah nyata dan menggunakan matematika secara bermakna.

\section{METODE PENELITIAN}

Penelitian ini merupakan penelitian pengembangan. Model pengembangan yang digunakan adalah model pengembangan Dick and Carey yang terdiri atas 10 tahap pengembangan.

Subjek dalam penelitian ini adalah siswa-siswi kelas X IPA-1 dan X IPA-2 SMA Negeri 17 Medan tahun ajaran 2020/2021 yang masing-masing kelas terdiri dari 36 siswa. Sedangkan objek dalam penelitian ini adalah perangkat pembelajaran matematika SMA Kelas X beorientasi model pembelajaran berbasis masalah yang dikembangkan materi trigonometri.

Perangkat pembelajaran yang dikembangkan berupa Rencana Pelaksanaan Pembelajaran (RPP), Buku Petunjuk Guru (BPG), Buku Siswa (BS), dan Lembar Aktivitas Siswa (LAS). Pengembangan 
Vol. 14, No. 1, Juni 2021

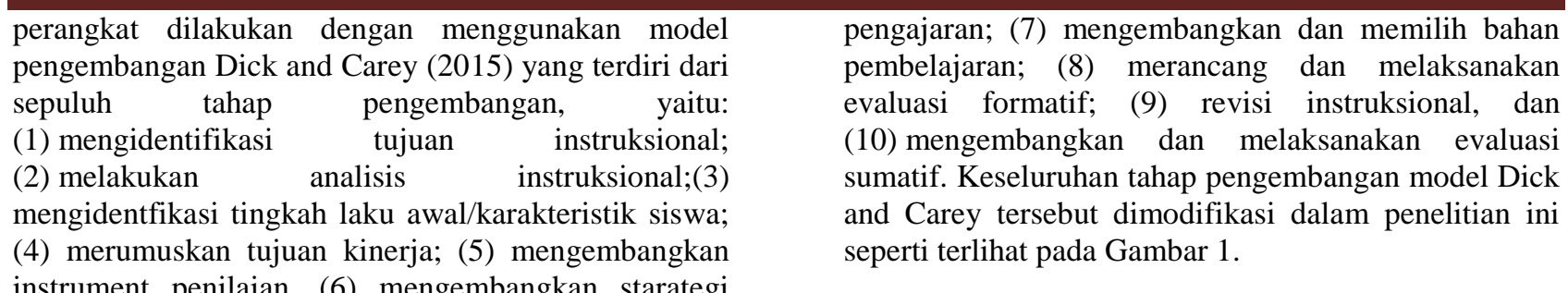
instrument penilaian, (6) mengembangkan starategi

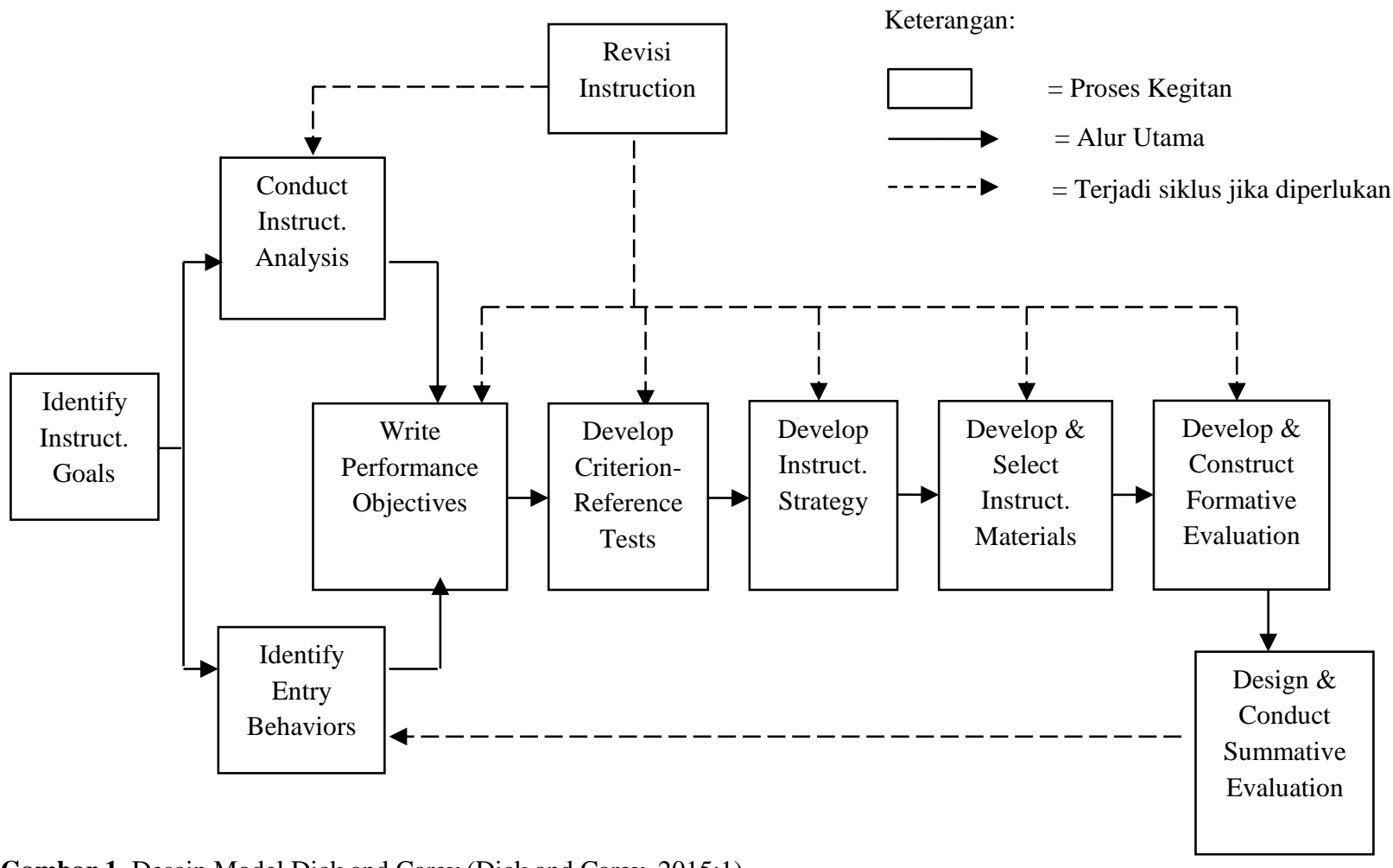

Gambar 1. Desain Model Dick and Carey (Dick and Carey, 2015:1)

Instrumen yang digunakan pada penelitian ini mencakup instrument untuk menilai kualitas perangkat pembelajaran yang meliputi 3 aspek yaitu aspek kevalidan, kepraktisan dan keefektifan. Instrumen yang digunakan berupa lembar observasi, angket, dan tes. Untuk lengkap dapat dilihat pada Tabel 1.

Tabel 1. Instrument Penelitian

\begin{tabular}{lllc}
\hline \multicolumn{1}{c}{ Aspek } & \multicolumn{1}{c}{ Instrumen } & \multicolumn{1}{c}{ Data Diperoleh } & Responden \\
\hline $\begin{array}{l}\text { Validitas Perangkat } \\
\text { Pembelajaran }\end{array}$ & Lembar validasi & $\begin{array}{l}\text { Validitas RPP, LKPD, BS, BPG, dan Tes } \\
\text { Kemampuan Pemecahan Masalah }\end{array}$ & Ahli dan Praktisi \\
\hline $\begin{array}{l}\text { Kepraktisan } \\
\text { Perangkat } \\
\begin{array}{l}\text { Pembelajaran } \\
$\cline { 2 - 3 }\end{array}\end{array} & $\begin{array}{l}\text { Pedoman } \\
\text { Wawancara }\end{array}$ & $\begin{array}{l}\text { Hasil wawancara terhadap siswa dan guru } \\
\text { terkait kemudahan penggunaan perangkat } \\
\text { pembelajaran. }\end{array}$ & Guru dan Siswa \\
\cline { 2 - 4 } $\begin{array}{l}\text { Keefektifan } \\
\text { Perangkat } \\
\text { Pembelajaran }\end{array}$ & Tembar observasi & Keterlaksanaan perangkat pembelajaran & Observer \\
\cline { 2 - 4 } & Lembar observasi & Aktivitas siswa & Subjek penelitian \\
\hline
\end{tabular}

Perangkat pembelajaran dikatakan valid jika memenuhi kriteria validitas isi dan validitas konstruk. Untuk validitas isi dilakukan oleh 5 validator dengan memberikan nilai 1 sampai 5 pada setiap kolom penilaian yang meliputi aspek berikut: 1) format, 2) bahasa, 3) isi, dan 4) ilustrasi. Perangkat pembelajaran berbasis masalah memenuhi validitas isi yang diharapkan jika rata-rata penilaian validator terhadap seluruh perangkat Selanjutnya dilakukan validitas konstruk terhadap tes kemampuan pemecahan masalah. Sebelum digunakan untuk ujicoba lapangan, butir-butir soal tes kemampuan pemecahan masalah di ujicoba di 
Vol. 14, No. 1, Juni 2021

luar subjek penelitian untuk mengukur validitas reliabilitas, daya pembeda dan tingkat kesukaran Validitas butir soal menggunakan pembelajaran berada pada kriteria minimal valid yaitu nilai rata-rata $\geq 4$. Jika tidak terpenuhi, maka perlu dilakukan kembali kegiatan validasi. Demikian seterusnya hingga diperoleh perangkat pembelajaran yang memenuhi kriteria valid. Selanjutnya dilakukan validitas konstruk terhadap tes kemampuan pemecahan masalah. Sebelum digunakan untuk ujicoba lapangan, butir-butir soal tes kemampuan pemecahan masalah di ujicoba di luar subjek penelitian untuk mengukur validitas dan reliabilitas. Validitas butir soal menggunakan rumus Correlations Product Moment (Sugiyono, 2019:228) dan reliabilitas menggunakan rumus Alpha-Cronbach (Arikunto, 2012).

Selanjutnya dilakukan uji daya pembeda dan tingkat kesukaran untuk dapat membedakan antara siswa siswa yang berkemampuan tinggi dengan siswa berkemampuan rendah, serta untuk mengetahui tingkat kesukan soal yang diberikan. Untuk mengetahui daya pembeda adalah dengan mengurangkan rata-rata nilai kelompok atas dengan rata-rata kelompok bawah dibagi dengan skor maksimum ideal. Untuk mengetahui tingkat kesukaran soal adalah dengan menjumlahkan nilai kelompok atas dijumlahkan dengan nilai kelompok bawah dibagi dengan banyak responden dikali skor maksimum.

Tabel 2. Persentase Waktu Ideal dan Batas Toleransi Aktivitas Siswa

\begin{tabular}{|c|c|c|c|c|}
\hline No. & Kategori Aktivitas siswa & Waktu Ideal & Interval Toleransi PWI & Kriteria Ideal \\
\hline 1. & $\begin{array}{l}\text { Memperhatikan/men-dengarkan penjelasan } \\
\text { guru/teman }\end{array}$ & $25 \%$ dari WT & $20 \% \leq \mathrm{PWI} \leq 30 \%$ & \multirow{5}{*}{$\begin{array}{c}\text { Tiga dari } 1,2,3, \\
4,5 \text { dipenuhi } \\
\text { dan } 3,4 \text { harus } \\
\text { dipenuhi }\end{array}$} \\
\hline 2. & $\begin{array}{l}\text { Membaca buku siswa (BS) dan lembar } \\
\text { kerja peserta didik (LKPD) }\end{array}$ & $15 \%$ dari WT & $10 \% \leq \mathrm{PWI} \leq 20 \%$ & \\
\hline 3. & $\begin{array}{l}\text { Mencatat penjelasan guru, mencatat dari } \\
\text { buku, menyelesaikan masalah pasa LKPD, } \\
\text { merangkum pekerjaan kelompok }\end{array}$ & $30 \%$ dari WT & $25 \% \leq \mathrm{PWI} \leq 35 \%$ & \\
\hline 4. & $\begin{array}{l}\text { Berdiskusi/bertanya, mengajukan ide, } \\
\text { antara siswa dan temannya atau antara } \\
\text { siswa dan guru, serta menarik kesimpulan } \\
\text { suatu prosedur atau konsep }\end{array}$ & $30 \%$ dari WT & $25 \% \leq \mathrm{PWI} \leq 35 \%$ & \\
\hline 5. & $\begin{array}{l}\text { Melakukan prilaku yang tidak relevan } \\
\text { dengan pembelajaran }\end{array}$ & $0 \%$ dari WT & $0 \% \leq \mathrm{PWI} \leq 5 \%$ & \\
\hline
\end{tabular}

Keterangan:

PWI adalah persentase waktu ideal

WT adalah waktu tersedia pada setiap pertemuan.

Kepraktisan perangkat pembelajaran ditinjau berdasarkan penilaian para validator, respon guru dan siswa berdasarkan hasil wawancara, serta keterlaksanaan perangkat pembelajaran. Penilaian validator terpenuhi jika pada lembar validasi seluruh validator menyatakan bahwa perangkat pembelajaran dapat digunakan dengan mudah. Hasil wawancara menunjukkan bahwa guru dan siswa menyatakan bahwa perangangkat dapat digunakan dengan mudah. Kriteria keterlaksanaan perangkat pembelajaran terpenuhi jika persentase keterlaksanaan perangkat pembelajaran $\geq 80 \%$.

Keefektifan perangkat pembelajaran ditinjau berdasarkan: 1) ketuntasan hasil belajar siswa secara klasikal berdasarkan tes kemampuan pemecahan masalah, 2) aktivitas siswa selama kegiatan pembelajaran, dan 3) respon siswa terhadap komponen dan perangkat pembelajaran. Ketuntasan hasil belajar siswa dilihat berdasarkan hasil tes kemampuan pemecahan masalah,. Ketuntasan hasil belajar siswa secara klasikal terpenuhi jika $\geq 85 \%$ memperoleh nilai tes $\geq 2,67$ dari skala 4. Aktivitas siswa ditinjau bedasarkan rata-rata penilaian observer dari seluruh pertemuan pada setiap aspek aktivitas yang diamati. Kriteria efektivitas berdasarkan aktivitas siswa tercapai jika memenuhi persentase toleransi waktu ideal yang ditetapkan (Sinaga 2007). Adapun kriteria aktivitas siswa berdasarkan pencapaian toleransi waktu ideal yang ditetapkan dapat di lihat pada Tabel 2.

Respon siswa ditinjau berdasarkan jawaban siswa terhadap angket yang diberikan. Kriteria efektivitas berdasarkan respon siswa terpenuhi jika secara klasikal $\geq 80 \%$ subjek memberikan respon positif (Sinaga, 2007), yaitu terhadap seluruh aspek yang ditanyakan terkait perangkat dan pelaksanaan pembelajaran. Hasil respon siswa di dapatkan ketika melakukan uji coba lapangan bersamaan dengan melihat watu ideal dan batas toleransi aktivitas siswa serta respon siswa di dalam pembelajaran.

\section{HASIL PENELITIAN}

Pengembangan perangkat pembelajaran telah selesai dilakukan dengan menggunakan model pengembangan Dick and Carey dengan rincian sebagai berikut.

\section{Tahap Identifikasi Tujuan Instruksional}

Tujuan pengajaran dapat diidentifikasi dengan terlebih dulu menganalisis kebutuhan instruksional. Proses mengidentifikasi kebutuhan instruksional dimulai dari mengidentifikasi masalah yang di lapangan. Bedasarkan tes diagnostik yang diberikan, 
kemampuan pemecahan masalah siswa masih rendah dengan persetase ketuntasan 33,333\% . Hasil observasi dan wawancara dengan guru dan siswa menunjukkan bahwa penyebabnya adalah siswa tidak terbiasa memecahkan masalah dalam kegiatan pembelajaran. Hal ini juga didukung dengan keadaan guru yang belum mampu menyusun perangkat pembelajaran yang fokus dalam mengembangkan kemampuan pemecahan masalah siswa. Berdasarkan temuan tersebut, maka tujuan utama dalam pengembangan perangkat ini adalah mengambangkan dan meningkatkan kemampuan pemecahan masalah siswa.

\section{Tahap Melakukan Analisis Instruksional}

Analisis instruksional dalam penelitian ini sebagai proses menjabarkan kompetensi umum menjadi subkompetensi, kompetensi dasar atau subkompetensi khusus yang tersusun secara logis dan sistematik. Kegiatan tersebut dimaksudkan untuk mengidentifikasi daftar subkompetensi dan menyusun hubungan antara satu dengan yang lain menuju kompetensi umum yang dalam kurikulum 2013 disebut kompetensi inti. Materi yang akan diajarkan adalah perbandingan trigonometri. Sehingga dijabarkan kompetensi dasar dari materi tersebut, dan dikembangkan indikator-indikator untuk mencapai keberhasilannya.

\section{Tahap Mengidentifikasi Karakteristik Siswa}

Perkembangan kognitif subjek penelitian di SMA Negeri 17 Medan memasuki tahap operasional formal karena berada pada rentang usia 15-16 tahun. Tahap tersebut ditandai dengan cara berpikir yang lebih logis, abstrak, dan idealistik. Subjek sasaran di kelas X adalah siswa yang cukup heterogen, baik dilihat dari jenis kelamin dan kemampuan kognitif siswa.

\section{Tahap Merumuskan Tujuan Kinerja}

Penulisan rumusan tujuan pembelajaran didasarkan pada indikator untuk mencapai kompetensi dasar yang telah disusun pada tahap pengembangan kedua. Adapun tujuan pembelajaran dalam penelitian ini yaitu : (1) siswa dapat menentukan konsep dasar sudut; (2) siswa dapat menentukan perbandingan sudut; (3) siswa dapat menentukan sudut dalam bentuk radian; (4) siswa dapat menentukan nilai sinus, cosinus, tangen, secan, cosecant, dan cotangent pada suatu segitig siku-siku; (5) siswa dapat menyelesaikan masalah perbandingan trigonometri yang berkaitan dengan masalah dalam kehidupan sehari-hari.

\section{Tahap Mengembangkan Instrument Penilaian}

Pada tahap ini disusun tes hasil belajar untuk mengukur kemampuan pemecahan masalah siswa. Tes disusun berdasarkan tujuan pembelajaran yang akan dicapai. Berdasarkan tujuan tersebut disusun tes essay sebanyak 4 masalah dan setiap masalah disertai dengan pertanyaan-pertanyaan proses pemecahan masalah.

\section{Tahap Mengembangkan Strategi Pengajaran}

Mengembangkan srategi pembelajaran, yang secara spesifik untuk membantu pembelajar untuk mencapai tujuan khusus. Sesuai dengan inti dari penelitian ini adalah mengembangkan perangkat pembelajaran yang berorientasi pembelajaran berbasis masalah. Adapun sintaks pembelajaran berbasis masalah dapat dilihat pada Tabel 3.

Tabel 3. Sintaks Pembelajaran Berbasis Masalah

\begin{tabular}{|c|c|c|}
\hline No & Tahap & Tingkah Laku Guru \\
\hline 1. & $\begin{array}{l}\text { Orientasi siswa } \\
\text { kepada masalah }\end{array}$ & $\begin{array}{l}\text { Guru menjelaskan } \\
\text { tujuan pembelajaran, } \\
\text { menjelaskan media } \\
\text { yang dibutuhkan, } \\
\text { memotivasi siswa } \\
\text { terlibat pada aktivitas } \\
\text { pemecahan masalah } \\
\text { yang dipilihnya. }\end{array}$ \\
\hline 2. & $\begin{array}{l}\text { Mengorganisasikan } \\
\text { siswa untuk belajar }\end{array}$ & $\begin{array}{l}\text { Guru membantu siswa } \\
\text { mendefenisikan dan } \\
\text { mengorganisasikan } \\
\text { tugas belajar yang } \\
\text { berhubungan dengan } \\
\text { masalah. }\end{array}$ \\
\hline 3. & $\begin{array}{l}\text { Membimbing } \\
\text { penyelidikan } \\
\text { individual maupun } \\
\text { kelompok }\end{array}$ & $\begin{array}{l}\text { Guru mendorong siswa } \\
\text { mengumpulkan } \\
\text { informasi yang sesuai, } \\
\text { melaksanakan } \\
\text { eksperimen untuk } \\
\text { mendapatkan } \\
\text { penjelasan dan } \\
\text { pemecahan masalah. }\end{array}$ \\
\hline 4. & $\begin{array}{l}\text { Mengembangkan } \\
\text { dan menyajikan } \\
\text { hasil karya }\end{array}$ & $\begin{array}{l}\text { Guru membantu siswa } \\
\text { dalam merencanakan } \\
\text { dan menyajikan karya } \\
\text { dan membantu siswa } \\
\text { untuk berbagai tugas } \\
\text { dengan temannya. }\end{array}$ \\
\hline 5. & $\begin{array}{l}\text { Menganalisis dan } \\
\text { mengevaluasi } \\
\text { proses pemecahan } \\
\text { masalah }\end{array}$ & $\begin{array}{l}\text { Guru membantu siswa } \\
\text { untuk melakukan } \\
\text { refleksi atau evaluasi } \\
\text { terhadap penyelisikan } \\
\text { siswa dan proses yang } \\
\text { siswa gunakan. }\end{array}$ \\
\hline
\end{tabular}

\section{Tahap Mengembangkan dan Memilih Bahan Pembelajaran}

Kegiatan utama pada fase ini adalah desain penulisan rancangan pembelajaran yang meliputi Rencana Pelaksanaan Pembelajaran (RPP), Lembar Kerja Peserta Didik (LKPD), Buku Petunjuk Guru (BPG), Buku Siswa (BS) dan Tes Kemampuan Pemecahan Masalah (TKPM). Bahan pembelajaran yang disusun didasarkan pada $\mathrm{KI}, \mathrm{KD}$, dan indikator pada materi perbandingan trigonometri, serta disesuaikan dengan tujuan untuk melatih dan meningkatkan kemampuan pemecahan masalah siswa. Semua perangkat pembelajaran satu kesatuan dalam model pembelajaran berbasis masalah. Berikut adalah gambar desain tampilan perangkat. 


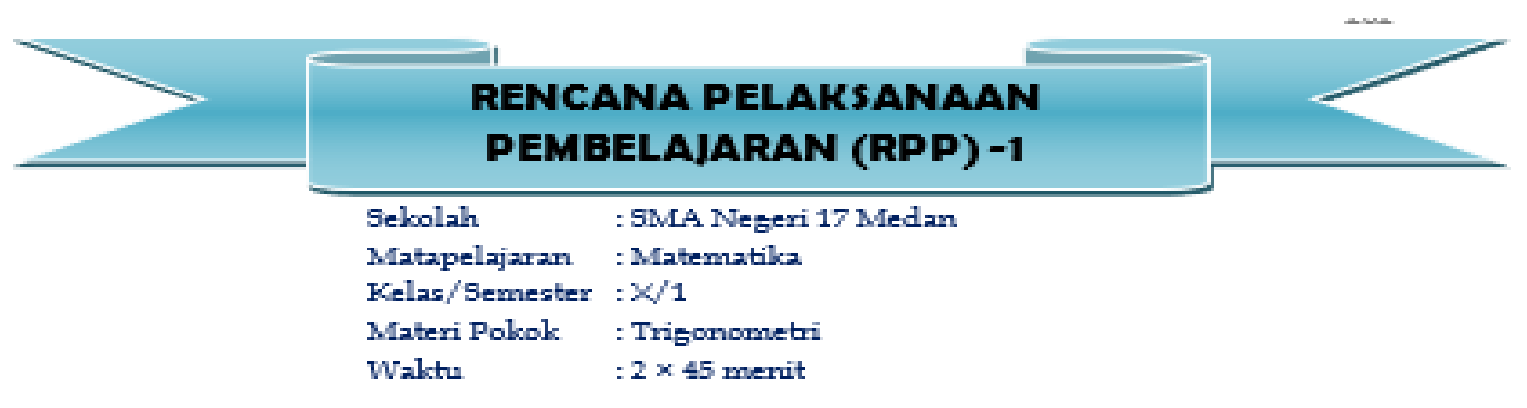

\section{A. Kompetensi Inti SMLA}

RI 1: Menghayati dan mengamallcan ajaran agama yang dianutuya.

KI 2: Menunjublcan perilaku jujux, disiplin, tangsung jawab, peduli (sotong royons, berjasama, toleran, damai), santum, responsif, dan pro-alktif sebagai bagian dari solusi atas berbagai permasalahan dalam berinteralksi secara efektif dengan linglumsan sosial dan alam serta menempatkan diri sebasai cerminam banssa dalam pergaulan dunia.

RI 3: Memahami, menerapkan dan mensanalisis pengetahuan faktual, bonseptual, prosedural berdasarkan rasa ingintahurya tentang ilmu pensetahuan, telcnologi. seni, budaya, dan humaniora dengan wawasan bemanusiaan, bebangsaan, benegaraan, dan peradaban terkait perryebab fenomena dan kejadian serta meneraplan pensetahuan prosedural pada bidans kajian yans spesifik sesuai dengan bakcat dan minatrya untuk memecalukan masalah.

KI 4: Mengolah, menalax, dan menyaji dalam ranah konkoret dan ranah abatrak terkait dengan pengembansan dari yans dipelajaxinya di seloolah secara mandiri. dan mampu mengsunakan metoda sesuai kaidah keilmuan.

Gambar 2. Desain RPP

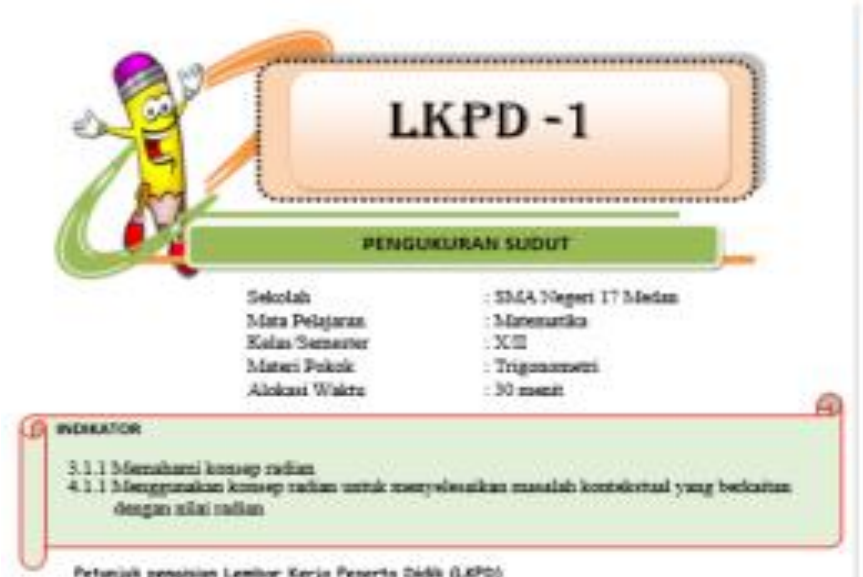

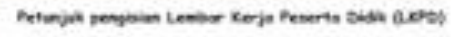

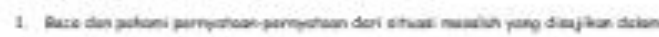

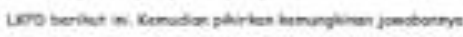

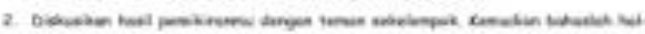

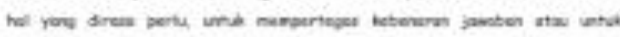

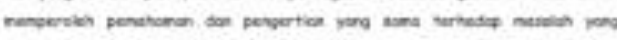

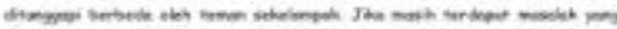

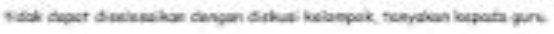

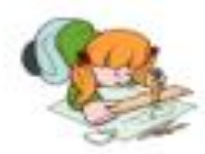

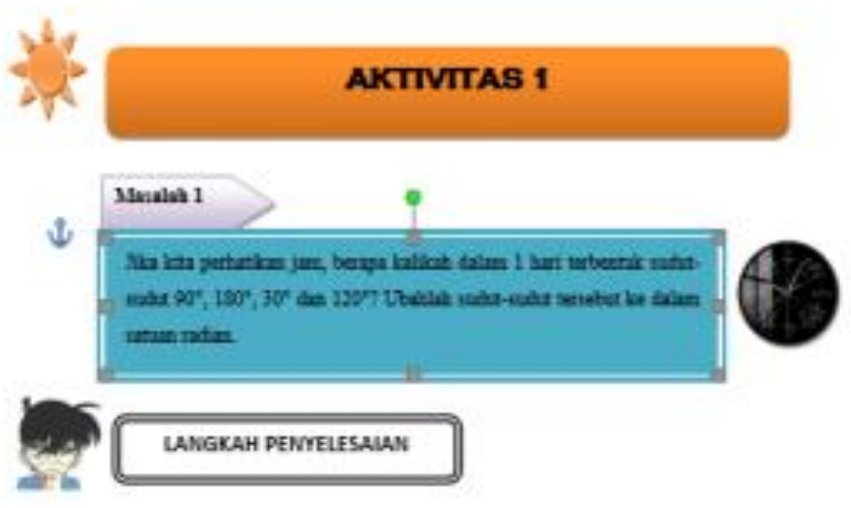

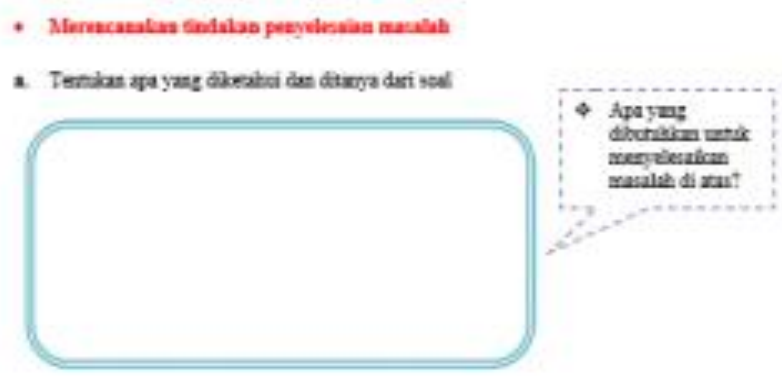

Gambar 3. Desain LKPD 

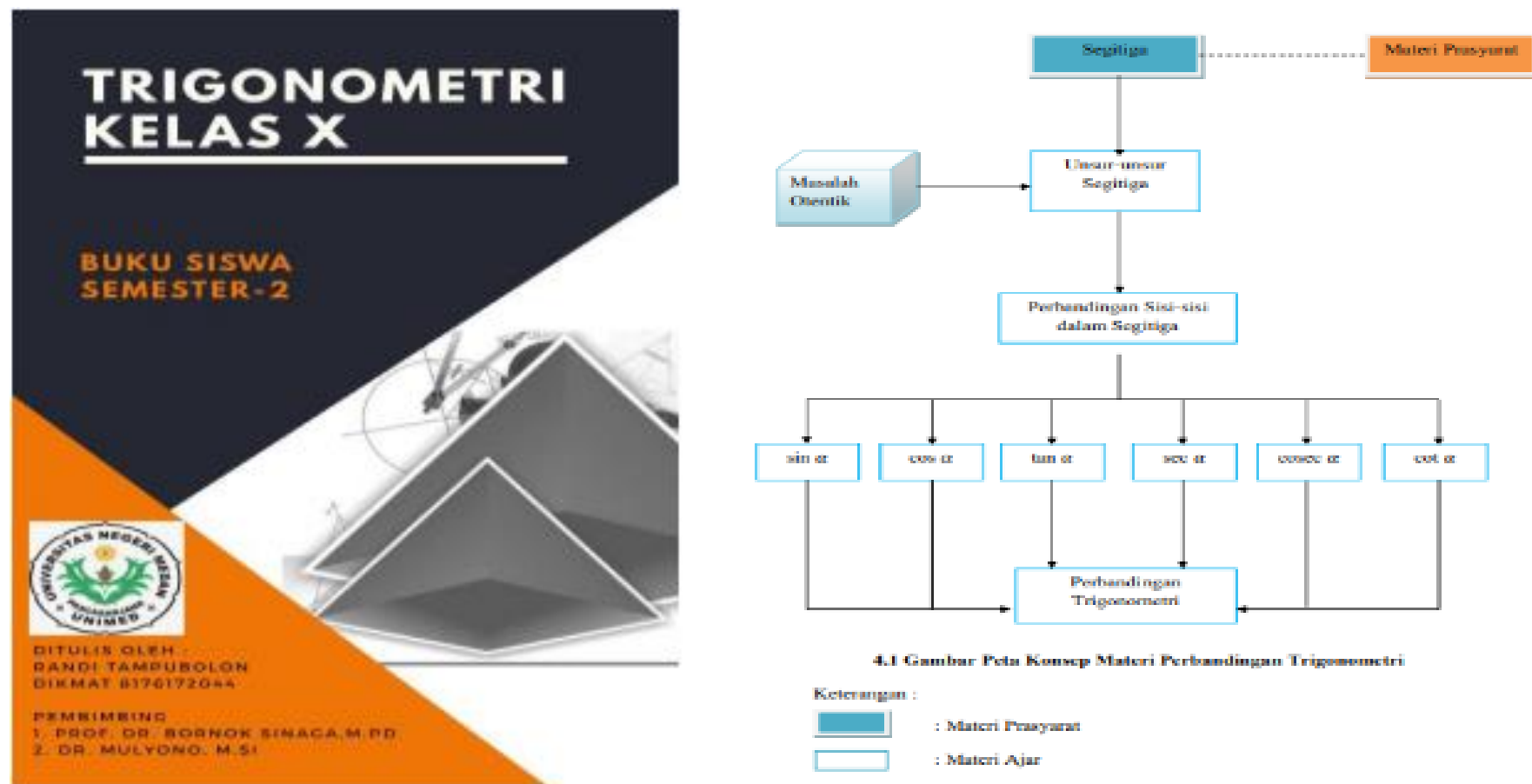

Gambar 4. Desain Buku

TES KEMLAMPUAN PEMIECAHAN

MASALAH MATEMLATIS

Petunjule:

Jawablah soal-soal di bawah ini dengan lengkap dan jelas

1. Seorang pengamat berada di puncak mercusuar. Kapal A dan kapal B yang menuju ke pelabuhan Ajibata (Danau Toba Parapart), berada gatu garis lurus dengan bagian bawah mercusuar $\mathrm{M}$, terlihat masing-masing dengan sudut depreai $45^{\circ}$ dan $30^{\circ}$. Jika tinggi mercuguar dari permukcaan air laut adalah 90 meter, maka hitunglah jarak kapal A dan kapal B.

a. Tentukan apa yang diketahui dan ditamya dari soal

b. Apa langkah yang digunakan untuk menyelesaikan masalah tersebut?

c. Bagaimana proses penyelesaian dari masalah tersebut?

d. Apakah jawaban dari penyelesaian tersebut sudah benar, berikan alasan anda. Apakah ada cara lain untuk menyelesaikan masalah tersebut?

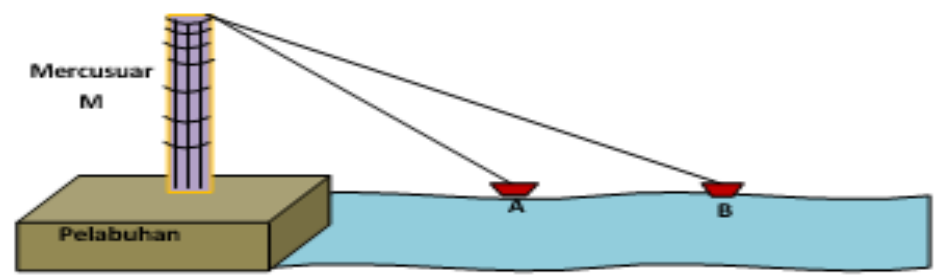

Gambar 5. Desain Tes Kemampuan Pemecahan Masalah

Tahap Merancang dan Melaksanakan Evaluasi Formatif

Pada tahap ini dilakukan evaluasi terhadap perangkat pembelajaran yang telah selesai dikembangkan. evaluasi formatif dilakukan dengan 2 tahap, yaitu: 1) evaluasi satu-satu oleh ahli dan praktisi, dan 2) uji coba lapangan. Tujuannya adalah untuk melihat kelemahan dan memperbaiki perangkat yang sudah dikembangkan. Hasil evaluasi satu-satu oleh ahli dan praktisi berupa penilaian validitas isi menunjukkan 
Vol. 14, No. 1, Juni 2021

bahwa seluruh perangkat pembelajaran memenuhi kriteria valid dapat dilihat pada Tabel 4.

Tabel 4. Rangkuman Hasil Validasi Perangkat Pembelajaran

\begin{tabular}{clcc}
\hline No. & $\begin{array}{c}\text { Objek yang } \\
\text { dinilai }\end{array}$ & $\begin{array}{c}\text { Nilai rata-rata } \\
\text { total validitas }\end{array}$ & $\begin{array}{c}\text { Tingkat } \\
\text { Validitas }\end{array}$ \\
\hline 1. & RPP & 4,47 & \\
2. & LKPD & 4,34 & Valid \\
3. & BPG & 4,38 & \\
4. & BS & 4,34 & \\
\hline
\end{tabular}

Setelah perangkat pembelajaran dikatakan valid, selanjutnya dilakukan uji validitas dan reabilitas dan dapat kita lihat dalam Tabel 5

Tabel 5. Hasil Validitas dan Reabilitas Butir Soal

\begin{tabular}{|c|c|c|c|c|c|}
\hline No. & $r_{x y}$ & $t_{\text {hitung }}$ & $t_{\text {tabel }}$ & $r_{11}$ & Interpretasi \\
\hline 1. & 0,895 & 11,699 & 2,05 & \multirow{4}{*}{0,922} & \multirow{4}{*}{$\begin{array}{c}\text { Valid dan } \\
\text { Sangat } \\
\text { Tinggi }\end{array}$} \\
\hline 2. & 0,909 & 12,716 & 2,05 & & \\
\hline 3. & 0,911 & 12,880 & 2,05 & & \\
\hline 4. & 0,897 & 11,832 & 2,05 & & \\
\hline
\end{tabular}

Dari hasil validitas dan reabilitias butir soal di dapat juga hasil daya pembeda dengan kategori baik dan tingkat kesukaran soal dengan kategori sedang.

Uji coba lapangan atau uji coba I dilakukan untuk melihat kepraktisan dan keefektifan perangkat pembelajaran. Pada uji coba I perangkat pembelajaran belum memenuhi seluruhkriteria praktis dan efektif, sehingga harus dilakukan revisi terhadap perangkat pembelajaran serta dilakukan kembali uji coba II.

\section{Tahap Revisi Instruksional}

Revisi dilakukan berdasarkan temuan kelemahankelemahan perangkat pada uji coba I. Revisi dilakukan pada RPP terkait alokasi waktu pembelajaran, serta pada LKPD dan BS terkait materi yang diajarkan. Setelah revisi selesai, dilakukan uji coba lapangan lanjutan atau uji coba II untuk melihat kembali kepraktisan dan keefektifan perangkat pembelajaran, serta peningkatan kemampuan pemecahan masalah siswa antar uji coba.

\section{Tahap Mengembangkan dan Melaksanakan Evaluasi Sumatif}

Evaluasi sumatif dalam penelitian ini tidak dilakukan. Hal ini karena evaluasi sumatif bukan bagian dari proses desain instruksional (Dick, Carey and Carey 2015). Evaluasi formatif dan evaluasi sumatif tidak bisa dirangkaikan sebagai dua kegiatan berturut-turut, namun diselingi masa implementasi (Mustafa, 2020). Sehingga membutuhkan waktu yang lama dan biaya yang banyak untuk melakukannya.

\section{Deskripsi Hasil Uji Coba I}

Uji Coba I dilakukan di kelas X IPA-2 dan yang akan dilakukan adalah untuk mengukur tingkat kepraktisan, tingkat kefektifan dan peningkatan kemampuan siswa terhadap perangkat pembelajaran yang dikembangkan dengan model berbasis masalah. Kriteria kepraktisan perangkat pembelajaran berdasarkan penilaian validator terpenuhi, karena seluruh validator menilai perangkat pembelajaran yang dikembangkan dapat digunakan dengan mudah. Hasil wawancara guru dan siswa memperoleh informasi bahwa perangkat pembelajaran dapat digunakan dengan mudah. Keterlaksanaan perangkat pembelajaran terpenuhi, ditinjau dari rata-rata seluruh pertemuan pembelajaran memperoleh persentase 81.46\% (kategori baik). Berdasarkan deskripsi tersebut, maka perangkat pembelajaran yang dikembangkan memenuhi kriteria praktis.

Hasil tes kemampuan pemecahan masalah secara klasikal menunjukkan jumlah subjek yang tuntas memperoleh nilai $\geq 2,67$ mencapai 14 siswa dari 36 siswa atau 38,89\%. Sehingga belum memenuhi kriteria ketuntasan hasil belajar klasikal yang diharapkan. Hasil ketuntasan klasikal ujicoba I ditunjukkan pada Tabel 6.

Tabel 6. Ketuntasan Klasikal Ujicoba I

\begin{tabular}{lcc}
\hline \multirow{2}{*}{ Kategori } & \multicolumn{2}{c}{ Kemampuan Pemecahan Masalah } \\
\cline { 2 - 3 } & Jumlah siswa & Persentase \\
\hline Tuntas & 14 & $38,89 \%$ \\
\hline Tidak tuntas & 12 & $61,11 \%$ \\
\hline Jumlah & 36 & $100 \%$ \\
\hline
\end{tabular}

Selanjutnya kriteria keefektifan adalah berdasarkan aktivitas siswa dimana dalam setiap kategori dapat dilihat pada Tabel 7.

Tabel 7. Persentase Aktivitas Siswa Ujicoba I

\begin{tabular}{cccccc}
\hline \multirow{2}{*}{ Pertemuan } & \multicolumn{5}{c}{ Persentase Aktivitas Siswa } \\
\cline { 2 - 6 } & 1 & 2 & 3 & 4 & 5 \\
\hline I $\left(2 \times 45^{\circ}\right)$ & 23,96 & 15,63 & 33,33 & 22,92 & 4,17 \\
\hline II $\left(2 \times 45^{\circ}\right)$ & 22,92 & 13,54 & 34,38 & 26,04 & 3,13 \\
\hline III 2 x 45 $)$ & 20,83 & 15,63 & 34,38 & 21,88 & 7,29 \\
\hline Rata-rata & 22,57 & 14,93 & 34,04 & 23,61 & 4,86 \\
\hline Kriteria & \multicolumn{5}{c}{ Terpenuhi } \\
\hline
\end{tabular}

Data respon siswa dijaring untuk melihat sejauh mana ketertarikan, perasaan senang, keterkinian, serta kemudahan siswa dalam memahami komponenkomponen perangkat pembelajaran berorientasi model pembelajaran berbasis masalah yang dikembangkan, Angket respon siswa memiliki respon positif dan respon negatif. Respon positif ditandai dengan pernyataan-pernyataan positif seperti senang, baru, berminat, jelas, tertarik.Sedangkan pernyataan negatif ditandai dengan pernyataan-pernyataan seperti tidak senang, tidak baru, tidak berminat, tidak jelas dan tidak tertarik dalam menggunakan komponen perangkat pembelajaran berbasis masalah. Hasil analisis data angket respon siswa terhadap komponen perangkat pembelajaran yang dikembangkan disajikan pada Tabel 8. Dari seluruh siswa memberikan respon positif terhadap perangkat pembelajaran yang diberikan sehingga mencapai $89,11 \%$ menyatakan bahwa respon siswa siswa sangat positif. 
Vol. 14, No. 1, Juni 2021

\begin{tabular}{|c|c|c|c|}
\hline \multirow[b]{2}{*}{ No } & \multirow{2}{*}{ Aspek } & \multicolumn{2}{|c|}{ (\%) Rata-Rata } \\
\hline & & Senang & Tidak \\
\hline 1 & $\begin{array}{l}\text { Perasaan senang siswa } \\
\text { terhadap komponen } \\
\text { pembelajaran. }\end{array}$ & 91,67 & 8,33 \\
\hline & Jawaban & Baru & Tidak \\
\hline 2 & $\begin{array}{l}\text { Respon siswa terhadap } \\
\text { kebaruan komponen } \\
\text { pembelajaran. }\end{array}$ & 87,78 & 12,22 \\
\hline & Jawaban & Berminat & Tidak \\
\hline 3 & $\begin{array}{l}\text { Respon siswa terhadap } \\
\text { keberminatan untuk } \\
\text { mengikuti } \\
\text { pembelajaran } \\
\text { selanjutnya. }\end{array}$ & 97,22 & 2,78 \\
\hline & Jawaban & Jelas & Tidak \\
\hline 4 & $\begin{array}{l}\text { Penilaian siswa } \\
\text { terhadap kejelasan } \\
\text { bahasa yang } \\
\text { digunakan. }\end{array}$ & 90,28 & 9,72 \\
\hline & Jawaban & Tertarik & Tidak \\
\hline 5 & $\begin{array}{l}\text { Respon siswa terhadap } \\
\text { ketertarikan dengan } \\
\text { penampilan (tulisan, } \\
\text { ilustrasi/ gambar dan } \\
\text { letak gambar). }\end{array}$ & 86,11 & 13,89 \\
\hline & ta-Rata Keseluruhan & 89,81 & 10,19 \\
\hline
\end{tabular}

Kemudian dalam mengetahui tingkat kemampuan pemecahan masalah siswa diperoleh dari data pre-test dan post-test. Peningkatan kemampuan pemecahan masalah disajikan dalam Tabel 9.

Tabel 9. Peningkatan Kemampuan Pemecahan Masalah Uji Coba I

\begin{tabular}{cccc}
\hline \multirow{2}{*}{ Peningkatan } & $\begin{array}{c}\text { Rata-rata N- } \\
\text { Gain Nilai }\end{array}$ & $\begin{array}{c}\text { N-Gain } \\
\text { Nilai } \\
\text { Persen }\end{array}$ & Kriteria \\
\cline { 2 - 4 } & 0,32 & $32,41 \%$ & Rendah \\
\hline
\end{tabular}

Secara keseluruhan perangkat pembelajaran yang dikembangkan memenuhi kriteria valid dan praktis, namun belum memenuhi kriteria keefektifan Hal ini dikarenakan aspek ketuntasan hasil belajar siswa secara klasikal belum terpenuhi. Dengan demikian perangkat pembelajaran harus dilakukan revisi dan selanjutnya dilakukan uji coba II. Untuk Uji Coba II dilakukan dikelas yang berbeda yaitu di kelas X IPA-1.

\section{Deskripsi Hasil Uji Coba II}

Kriteria kepraktisan perangkat pembelajaran berdasarkan penilaian validator terpenuhi sesuai dengan deskripsi pada uji coba I. Keterlaksanaan perangkat pembelajaran pada uji coba II juga terpenuhi, ditinjau dari rata-rata seluruh pertemuan pembelajaran memperoleh persentase 89,13\% (kategori baik).

Kriteria keefektifan ditinjau dari hasil tes kemampuan pemecahan masalah secara klasikal terpenuhi. Hasil kemampuan pemecahan masalah ujicoba II dapat di lihat dalam Tabel.10.

\begin{tabular}{lcc}
\multicolumn{2}{c}{ Tabel 10. Ketuntasan Klasikal Ujicoba II } \\
\hline \multirow{2}{*}{ Kategori } & \multicolumn{2}{c}{ Kemampuan Pemecahan Masalah } \\
\cline { 2 - 3 } & Jumlah siswa & Persentase \\
\hline Tuntas & 33 & $91,67 \%$ \\
\hline Tidak tuntas & 3 & $8,33 \%$ \\
\hline Jumlah & 36 & $100 \%$ \\
\hline
\end{tabular}

Selanjutnya berdasarkan aktivitas siswa dimana dalam setiap kategori dapat dilihat pada Tabel 11.

Tabel 11. Persentase Aktivitas Siswa Ujicoba II

\begin{tabular}{cccccc}
\hline \multirow{2}{*}{ Pertemuan } & \multicolumn{5}{c}{ Persentase Aktivitas Siswa } \\
\cline { 2 - 6 } & 1 & 2 & 3 & 4 & 5 \\
\hline I $(2 \times 45)$ & 23,96 & 15,63 & 33,33 & 22,92 & 4,17 \\
\hline II $\left(2 \times 45^{\prime}\right)$ & 22,92 & 13,54 & 34,38 & 26,04 & 3,13 \\
\hline III 2 x 45') & 20,83 & 15,63 & 34,38 & 21,88 & 7,29 \\
\hline Rata-rata & 22,57 & 14,93 & 34,04 & 23,61 & 4,86 \\
\hline Kriteria & \multicolumn{5}{c}{ Terpenuhi } \\
\hline
\end{tabular}

Data respon siswa dijaring untuk melihat sejauh mana ketertarikan, perasaan senang, keterkinian, serta kemudahan siswa dalam memahami komponenkomponen perangkat pembelajaran berorientasi model pembelajaran berbasis masalah yang dikembangkan, untuk repon siswa untuk Uji Coba II disajikan dalam Tabel. 12.

Tabel 12. Respon Siswa Uji Coba II

\begin{tabular}{|c|c|c|c|}
\hline \multirow{2}{*}{ No. } & \multirow{2}{*}{ Aspek } & \multicolumn{2}{|c|}{ (\%) Rata-Rata } \\
\hline & & Senang & Tidak \\
\hline 1. & $\begin{array}{l}\text { Perasaan senang siswa } \\
\text { terhadap komponen } \\
\text { pembelajaran. }\end{array}$ & 94,44 & 5,46 \\
\hline & Jawaban & Baru & Tidak \\
\hline 2. & $\begin{array}{l}\text { Respon siswa terhadap } \\
\text { kebaruan komponen } \\
\text { pembelajaran. }\end{array}$ & 91,67 & 8,33 \\
\hline & Jawaban & Berminat & Tidak \\
\hline 3. & $\begin{array}{l}\text { Respon siswa terhadap } \\
\text { keberminatan untuk } \\
\text { mengikuti pembelajaran } \\
\text { selanjutnya. }\end{array}$ & 97,22 & 2,78 \\
\hline & Jawaban & Jelas & Tidak \\
\hline 4. & $\begin{array}{l}\text { Penilaian siswa } \\
\text { terhadap kejelasan } \\
\text { bahasa yang digunakan. }\end{array}$ & 91,67 & 8,33 \\
\hline & Jawaban & Tertarik & Tidak \\
\hline 5. & $\begin{array}{l}\text { Respon siswa terhadap } \\
\text { ketertarikan dengan } \\
\text { penampilan (tulisan, } \\
\text { ilustrasi/ gambar dan } \\
\text { letak gambar). }\end{array}$ & 91,67 & 8,33 \\
\hline & ata-Rata Keseluruhan & 93,33 & 6,73 \\
\hline
\end{tabular}

Dari seluruh siswa memberikan respon positif terhadap perangkat pembelajaran yang diberikan sehingga mencapai 89,11\% menyatakan bahwa respon siswa siswa sangat positif.

Kemudian dalam mengetahui tingkat kemampuan pemecahan masalah siswa diperoleh dari data pre-test 
Vol. 14, No. 1, Juni 2021

dan post-test. Peningkatan kemampuan pemecahan masalah disajikan dalam Tabel. 13.

Tabel 13. Peningkatan Kemampuan Pemecahan Masalah Uji Coba II

\begin{tabular}{cccc}
\hline \multirow{2}{*}{ Peningkatan } & $\begin{array}{c}\text { Rata-rata N- } \\
\text { Gain Nilai }\end{array}$ & $\begin{array}{c}\text { N-Gain } \\
\text { Nilai } \\
\text { Persen }\end{array}$ & Kriteria \\
\cline { 2 - 4 } & 0,53 & $53,24 \%$ & Sedang \\
\hline
\end{tabular}

Dari Tabel 13 di atas menunjukkan bahwa hasil $N$ Gain siswa yang ditinjau berdasarkan nilai rata-rata pre-test dan post-test kemampuan pemecahan masalah mengalami peningkatan. Berdasarkan hasil perhitungan $\mathrm{N}$-gain, diperoleh bahwa peningkatan kemampuan pemecahan masalah siswa pada uji coba II senilai 0,53 atau berkategori "Sedang". Dengan demikian penggunaan perangkat pembelajaran berorientasi model pembelajaran berbasis masalah yang dikembangkan dapat meningkatkan kemampuan pemecahan masalah siswa pada uji coba II.

\section{PEMBAHASAN}

Hasil penelitian menunjukkan bahwa perangakat pembelajaran berorientasi model pembelajaran berbasis masalah yang dikembangkan memenuhi kriteria valid, praktis, dan efektif. Hasil tersebut menunjukkan bahwa perangkat yang dikembangkan memiliki kualitas perangkat yang baik karena memenuhi kriteria valid, praktis, dan efektif (Sinaga, 2007). Setelah dihasilkan perangkat pembelajaran yang berkualitas baik, tujuan selanjutnya adalah penerapan perangkat pembelajaran yang dikembangkan mampu meningkatkan kemampuan pemecahan masalah.

Berangkat dari gagasan Polya tentang langkahlangkah pemecahan masalah, dapat dikatakan bahwa semua langkah yang dikemukakan mengarahkan kepada pengaturan siswa terhadap proses yang dilaksanakan untuk memperoleh solusi yang tepat. Polya (Purnomo, 2019:43) menyebutkan pemikirannya tersebut sebagai "berpikir tentang proses" (thinking about the process) dalam kaitannya dengan kesuksesan pemecahan masalah. Pemecahan masalah merupakan salah satu aspek yang sangat penting dalam pembelajaran matematika, NCTM (2007:52) mengatakan bahwa memecahkan masalah selain sebagai tujuan dari belajar matematika juga menjadi alat utama dalam belajar matematika.Selain itu Purnomo (2019:14) mengatakan "pemecahan masalah matematis telah lama dipandang sebagai aspek penting matematika, pengajaran matematika, dan pembelajaran matematika".

Sejalan dengan Barrow (Cahya, 2021: 29) menyebutkan dalam buku modul-model pengajaran dan pembelajaran mendefinisikan pembelajaran berbasis masalah (Problem Based Learning/ PBL) sebagai "learning gained through the process towards understanding the resolution of a problem. These problems are brought together first in the learning process". PBL merupakan salah satu bentuk peralihan dari paradigma pengajaran menuju paradigma pembelajaran. Jadi, fokusnya adalah proses pada pembelajaran siswa bukan pada pengajaran guru.

Proses pembelajaran pemecahan masalah Arends (Ramadhan, 2018:76) mengatakan bahwa "The five phases of problem-based learning and required teacher behaviors for each phase is: (1) Orient Students to the Problem, (2) Organize Students for Study, (3) Assist Independent and Group Investigation, (4) Develop and Present Artifacts and Exhibits. (5) Analyze and Evaluate the Problem-Solving Process". Pada pembelajaran berbasis masalah terdiri dari lima langkah utama yang dimulai dari guru memperkenalkan siswa dengan suatu masalah, mengorganisasikan siswa untuk belajar, membimbing penyelidikan individual maupun kelompok, mengembangkan dan mengembangkan hasil karya, dan diakhiri dengan menganalisis dan mengevaluasi proses pemecahan masalah.

Menurut Trianto (Siwu et al, 2021:48) model pembelajaran berbasis masalah merupakan suatu model pembelajaran yang didasarkan pada banyaknya permasalahan yang membutuhkan penyelidikan autentik yakni penyelidikan yang membutuhkan penyelesaian nyata dari permasalahan nyata. Pernyataan tersebut diperkuat oleh Suwanti et al (2021:7) dalam penelitian yang berjudul "Meningkatkan Kamampuan Pemecahan Masalah Matematika Melalui Model Pembelajaran Problem Based Learning (PBL)". Di dalam penelitian tersebut disimpulkan bahwa setiap siklus dalam tahap penelitian mengalami kenaikan dan tergolong ke dalam kategori sangat baik. Senada dengan hasil penelitian R Safithhri et al (2021:335) yang berjudul “ Pengaruh Penerapan Problem Based Learning (PBL) dan Project Based Learning (PjBL) Terhadap Kemampuan Pemecahan Masalah Berdasarkan Self Efficacy Siswa, yang menyimpulkan bahwa model Problem Based Learning mampu meningkatkan kemampuan kemampuan pemecahan masalah.

Subanindro (Siagian et al, 2019:1) menyatakan "Learning tools are a collection of learning resources arranged in such a way that students and teachers do learning activities. Learning tools are an important part of the learning process". Perangkat pembelajaran berfungsi untuk memberikan arah pelaksanaan pembelajaran sehingga menjadi terarah dan efisien. Sehingga dalam melaksanakan pembelajaran di kelas guru memiliki perlengkapan yang akan digunakan untuk melaksanakan pembelajaran berupa perangkat pembelajaran. Sabanindro Subanindro (Siagian et al, 2019:2) menyatakan bahwa "perangkat pembelajaran merupakan perangkat yang digunakan dalam proses pembelajaran. Perangkat pembelajaran berfungsi untuk memberikan arah pelaksanaan pembelajaran sehingga menjadi terarah dan efisien".

Selanjutnya Syamsiyah (Rahmadani et al, 2019: 2) menyatakan perangkat pembelajaran adalah salah satu wujud persiapan yang dilakukan oleh guru sebelum melakukan proses pembelajaran. Persiapan mengajar merupakan sebagian dari kesuksesan seorang guru. Jika dalam merencanakan gagal sama saja dengan merencanakan kegagalan. Hal ini mengisyaratkan 
betapa pentingnya melakukan persiapan pembelajaran melalui pengembangan perangkat pembelajaran. Selanjutnya di dalam Permendikbud 2016 menyatakan perangkat pembelajaran yang disusun perlu dipadukan dengan model-model pembelajaran yang sesuai untuk lebih tercapainya penguasaan berbagai kompetensi oleh siswa, yang meliputi kompetensi domain sikap/afektif, keterampilan/ psikomotorik, dan pengetahuan /kognitif.

Perangkat pembelajaran dikembangkan dengan menggunakan model pengembangan Dick and Carey. Perangkat pembelajaran yang dihasilkan adalah rencana pelaksanaan pembelajaran (RPP), lembar kerja peserta didik (LKPD), buku petunjuk guru (BPG), buku siswa (BS), dan tes kemampuan pemecahan masalah (TKPM). Setelah perangkat pembelajaran selesai dikembangkan, dilakukan uji coba lapangan. Hasil uji coba I menunjukkan bahwa perangkat pembelajaran memenuhi kriteria valid dan praktis, namun belum efektif. Hal ini dikarenakan aspek ketuntasan hasil belajar siswa secara klasikal belum terpenuhi. Dengan demikian perangkat pembelajaran dilakukan beberapa revisi, terutama pada RPP yang merupakan pedoman guru dalam pelaksanaan pembelajaran dan LKPD dan buku siswa yang merupakan pedoman siswa untuk diskusi kelompok dalam mengembangkan kemampuan pemecahan masalah siswa.

Selanjutnya dilakukan uji coba II, dimana perangkat pembelajaran dikembangkan telah memenuhi kriteria valid, praktis dan efektif. Hal ini sejalan dengan hasil penelitian Resky et al (2021) yang menunjukan bahwa pengembangan perangkat pembelajaran memenuhi kriteria valid, praktis, dan efektif dalam dua kali uji coba. Kemampuan pemecahan masalah siswa menggunakan perangkat pembelajaran berorientasi model pembelajaran berbasis masalah yang dikembangkan meningkat. Peningkatan didasarkan pada kenaikan nilai rata-rata TKPM siswa secara klasikal dari uji coba I ke uji coba II. Serta kenaikan nilai rata-rata TKPM siswa pada tiap-tiap indikator kemampuan pemecahan masalah dari uji coba I ke uji coba II.

\section{KESIMPULAN}

Berdasarkan hasil analisis dan pembahasan dalam penelitian ini, dikemukakan beberapa simpulan sebagai berikut: 1) Perangkat pembelajaran berbasis masalah yang dikembangkan memenuhi kriteria valid, ditinjau dari : a) validitas isi dan b) validitas konstruk. 2) Perangkat pembelajaran berbasis masalah yang dikembangkan memenuhi kriteria praktis, ditinjau dari: a) penilaian validator terhadap perangkat pembelajaran, b) wawancara siswa dan guru tentang kemudahan penggunaan perangkat, dan c) keterlaksanaan perangkat pembelajaran. 3) Perangkat pembelajaran berbasis masalah yang dikembangkan memenuhi kriteria efektif, ditinjau dari: a) ketuntasan hasil belajar siswa secara klasikal b) aktifitas siswa dalam kegiatan pembelajaran, dan c) respon positif siswa. 4) Kemampuan pemecahan masalah siswa menggunakan perangkat pembelajaran berbasis masalah yang dikembangkan meningkat, ditinjau dari perolehan N-Gain siswa pada akhir uji coba hingga kategori sedang.

\section{UCAPAN TERIMA KASIH}

Penulis menyampaikan terima kasih yang tulus dan penghargaan yang setinggi-tingginya kepada semua pihak yang telah membantu penulis, kepada keluarga yang telah mendukung penulis dalam segala hal. Penulis menyampaikan terima kasih kepada Prof. Dr. Pargaulan Siagian, M.Pd., Dr. Pardomuan Sitompul, M.Si., Mangaratua M. Simanjorang, M.Pd., Ph.D. atas masukan yang diberikan kepada Penulis sehingga penelitian ini dapat dilaksanakan dengan sebaikbaiknya. Penulis juga menyampaikan terima kasih kepada Kepala Dinas Pemprovsu, Kepala Sekolah SMA Negeri 17 Medan, serta guru-guru dan staf administrasi yang telah memberikan izin dan kesempatan kepada penulis untuk melakukan penelitian di sekolah tersebut.

\section{REFERENSI}

Arikunto, S. 2012. Prosedur Penelitian (Suatu Pendekatan Praktik). Yogyakarta : PT. Rineka Cipta

Bayuningsih, A. S., Usodo, B., \& Subanti, S. (2017). Analysis of Junior High School Students' Problemsolving Ability Reviewed from Self-regulated Learning. International Journal of Science and Applied Science: Conference Series, 2(1), 51.

Cahya Mega ,(2021). Metode Pembelajaran Berbasis Masalah di Pendidikan Usia Anak Usia Dini. Jurnal Tila : Tarbiyah Islamiyah Lil Athfaal. 1(1).20-41.

Dick W, Corey L,\& Corey J O. (2015). The Systematic Design of Intruction. Eighth Edition. Pearson.

Hasratuddin, (2018). Mengapa harus belajar metematika. Cetakan kedua: Perc. EDIRA. ISBN : 978-602-6970-45-9

Havill, J (2020). How to Solve It. In Discovering Computer Science.

Hutagalung R (2017). Pengembangan Perangkat Pembelajaran Model Guided Discovery Berbasis Budaya Batak Toba Untuk Meningkatkan Kemampuan Pemahaman Konsep Matematis Siswa SMP. Pythagoras : Jurnal Program Studi Pendidikan Matematika. 6(1). 37-52.

Mustafa PS., \& Winarno (2020). Pengembangan Buku Ajar Pengajaran Remedial Dalam Pendidikan Jasmani Untuk Mahasiswa S1 Pendidikan Jasmasni dan Kesehatan Universitas Negeri Malang. Multilateral : Jurnal Pendidikan Jasmani dan Olahraga 19(1), 1-20

North Central Regional Educational Laboratory (NCREL).(2007). Metacognition.

Purnomo D. (2019). Analisis Kemampuan Pemecahan Masalah Dalam Memecahkan Masalah Melalui Aktivitas Metakognisi Matematis. Pi: Mathematics Education Jurnal. 2(1). 40-53.

Ramadhan M R (2018). Tingkat Metakognisi Siswa Dalam Pembelajaran Pendidikan Agama Islam Berbasis Masalah. Tesis: Pascasarjana Universitas Islam Negeri Sunan Ampel. Surabaya. 
Vol. 14, No. 1, Juni 2021

R Reski, Hutapea N M, \& Saragih S. (2021). Pengembangan Perangkat Pembelajaran Berbasis Model Prolem Based Learning untuk Memfasilitasi Kemampuan Pemecahan Masalah Siswa Kelas VIII SMP/MTs. Jurnal Cendekia : Jurnal Pendidikan Matematika. 5(1). 701-717.

Safithri, R., Syaiful., \& Huda N (2021). Pengaruh Penerapan Problem Based Learning (PBL) dan Project Based Learnig (PjBL) Terhadap Kemampuan Pemecahan Masalah Berdasarkan Self Efficacy Siswa Jurnal Cendikia : Jurnal Pendidikan Matematika,5(1),335-346

Siagian T A, Armanto, \& Siagian P. (2021). Development of learning device oriented problem based learning to improve student's mathematical problem solving skill. IOPsience : Journal of Physics, Conferensi Series. 1731 (2021) 012056

Silalahi FCG., Kartini., \& Hutapea NM (2021). Pengembangan Perangkat Pembelajaran Matematika Berbasis Model Problem Based Learning untuk Memfasilitasi Kemampuan Pemecahan Masalah Matematis Peserta Didik Kelas VIII SMP. Jurnal Cendikia : Jurnal Pendidikan Matematika,5(1),113-124.

Sinaga, B. (2007). Pengembangan Model pembelajaran matematika Berdasarkan Masalah Berbasis Budaya Batak (PBMB3).Disertasi.Tidak dipublikasikan. Surabaya: PPs Universitas Negeri Surabaya.

Siwu B, Lawe YU,\& Rawa NR (2021). Pengaruh Pembelajaran Berbasis Masalah Terhadap Hasil Belajar IPA Kelas V SD Di Gugus VI Kecamatan Golewa Selatan Kabupaten Ngada. JCP : Jurnal Citra Pendidikan.1(1).45-58.

Sugiyono. (2019). Statistik Untuk Penelitian. Bandung: Alfabeta

Surya, E., Syahputra, E., dan Juniarti. (2018). Effect of Problem Based Learning Toward Mathematical Communication Ability and Self-Regulated Learning. Journal of Education and Practice, 9 (6): 14-23

Suwanti, Prasetyo E, Dhema M, \& Rusdin M E. (2021). Meningkatkan Kemampuan Pemecahan Masalah Metematika Melalui Model Pembelajaran Problem Based Learning (PBL). 6(1). 7-12.

Waluyo E.,\& Nurani . (2021). Pengembangan Desain Instruksional Model Inquiri Learning Terintegrasi Tpack Untuk Meningkatkan Kemampuan Pemecahan Masalah. JPPM : Jurnal Pengembangan Pembelajaran Matematika. 3(1). 1-11. 